\title{
Physical and Electrophoretic Characterization of Octadecyl Methacrylate-Based Monolithic Columns for Use in Capillary Electrochromatography
}

\author{
Valeska S. Aguiar and Carla B. G. Bottoli* \\ Instituto de Química, Universidade Estadual de Campinas (Unicamp) and \\ Instituto Nacional de Ciência e Tecnologia de Bioanalítica (INCTBio), \\ CP 6154, 13084-971 Campinas-SP, Brazil
}

\begin{abstract}
Colunas de alta eficiência cromatográfica de origem monolítica orgânica foram obtidas para uso em eletrocromatografia capilar (CEC) utilizando uma mistura de monômeros (concentrações constantes) com diferentes proporções de solventes porogênicos (1,4- butanodiol com álcool isoamílico, álcool amílico ou cicloexanol, na presença ou ausência de água). As fases estacionárias foram preparadas a partir do monômero precursor octadecilmetacrilato (ODMA), do agente de entrecruzamento etilenodimetacrilato (EDMA) e do monômero carregado ácido 2-acriloilamido2-metilpropanosulfóxido (AMPS), sendo este necessário para tornar a fase estacionária carregada negativamente, garantindo o fluxo eletrosmótico durante a análise. As colunas monolíticas foram caracterizadas fisicamente através de porosimetria e microscopia eletrônica de varredura (SEM), e eletrocromatograficamente, através de cálculo dos parâmetros cromatográficos de separação. A coluna mais eficiente foi preparada a partir dos solventes porogênicos álcool amílico:1,4-butanodiol na proporção 65:35 (v/v) e apresentou $38 \mu \mathrm{m}$ de altura de prato. Estas colunas foram aplicadas na separação de alquilparabenos e hidrocarbonetos policíclicos aromáticos (PAH).
\end{abstract}

Organic monolithic columns with high efficiency were obtained for use in capillary electrochromatography (CEC) from a mixture of monomers (constant concentrations) with different proportions of porogenic solvents (1,4-butanediol with isoamyl alcohol, amyl alcohol or cyclohexanol in the presence or absence of water). The stationary phases were prepared from the precursor monomer octadecyl methacrylate (ODMA), the cross-linking agent ethylene dimethacrylate (EDMA) and the ionizable monomer 2-acryloylamido-2-methylpropanesulfonic acid (AMPS), the latter being necessary to make the stationary phase negatively charged, assuring electrosmotic flow (EOF) during analysis. The monolithic columns synthesized were physically characterized by porosimetry and scanning electron microscopy (SEM), and electrochromatographically characterized by calculation of chromatographic parameters. The most efficient column was prepared using the porogenic solvent amyl alcohol:1,4-butanediol in a 65:35 (v/v) ratio and showed a plate height of $38 \mu \mathrm{m}$. These columns were applied for the separation of alkyl parabens and polycyclic aromatic hydrocarbons (PAH).

Keywords: capillary electrochromatography, monolithic stationary phases

\section{Introduction}

Capillary electrochromatography (CEC) is a hybrid technique of capillary electrophoresis (CE) and high performance liquid chromatography (HPLC). ${ }^{1,2}$ The CEC technique can be defined as a type of capillary electrophoresis carried out in packed capillary columns in an environment in which an applied electric field is responsible for the movement of the mobile phase across the capillary, generating the electrosmotic flow

*e-mail: carlab@iqm.unicamp.br
(EOF). ${ }^{3}$ Different from separations in zone capillary electrophoresis, the use of the stationary phase results in the separation of uncharged sample components. The major advantage of CEC compared to HPLC is the possibility of obtaining highly efficient columns while requiring smaller amounts of sample and mobile phase. ${ }^{4}$ The high efficiency obtained with the use of the CEC technique is due to the EOF profile, that is different of the profile achieved by the pressure application, occurred at the HPLC technique. The profile characteristic of the pressure flow is parabolic, while the profile of the EOF is laminar, what implies that the analytes will reach the 
detection local in the same time, generating narrow peaks and, consequently, efficient separations. ${ }^{1}$

Separation by CEC depends on several parameters, such as applied voltage, mobile phase composition, column temperature, type of buffer, capillary dimensions and, mainly, the stationary phase..$^{5,6}$ The latter is the most important parameter since its modification allows the separation of a wide variety of charged and uncharged analytes. ${ }^{7-12}$ The stationary phase present in the capillary can be particulate, wall-coated open-tubular or monolithic.

Capillary columns filled with particles require the presence of filters at their ends to prevent the loss of stationary phase from inside the capillary. These filters are placed in the capillaries through the process of sintering, which is difficult to reproduce. Furthermore, in CEC, the presence of these filters or frits is the main cause of air bubbles inside the capillary and the consequent reduction of electrical current during separations by CEC, and forms points of great fragility along the column. ${ }^{13-15}$ The frits are synthesized at high temperatures and this process can cause chemical modifications of the stationary phase on the silica surface found near the filters that can be a source of undesirable interactions. ${ }^{13,16}$

Wall-coated open-tubular capillaries contain the stationary phase as a coating on the inner wall of the tubes that can be chemically linked or physically or dynamically adsorbed. These columns present the disadvantage of a lower loading capacity due to the smaller area of the stationary phase and the unfavorable mobile phase to stationary phase volume ratio relative to particulate and monolithic columns. ${ }^{17}$

Due to the disadvantages observed with particulate and wall-coated open-tubular columns, the development of monolithic capillary columns containing extremely porous and easily synthesized material is of great current interest. The monoliths are prepared by polymerization processes in situ in a single step that also allows the grafting of charged species into the stationary phase, fundamental for assuring the electrosmotic flow. ${ }^{15,18}$ The development of monoliths is related to a combination of the better features of an analytical separation column, such as high loading capacity, minimal bubble formation, high separation efficiency and reduction of problems related to using frits, because they are not needed to retain the stationary phase. Two distinct types of monoliths have been used in CEC. One form possesses an inorganic backbone (silica columns), made by sol-gel technology, ${ }^{18-20}$ and the other possesses an organic backbone (organic polymer-based), such as acrylamides, acrylates, methacrylates or styrenes. . $^{3,6,14,21-44}$ Generally, organic polymeric monoliths have greater advantages than silica monoliths. The organic monoliths have high stability in different values of $\mathrm{pH}$ (2 to 12), inertness in biomolecule analyses and in analyses of molar mass molecules, as well as easy preparation and modification. These features are beneficial when there are biological samples of vast complexity. ${ }^{15,23}$

In addition, certain properties of the polymeric monolithic material can be easily controlled, such as porosity, surface area (smaller pores provide greater specific surface area) $)^{14,15,45,46}$ and functionality. ${ }^{6,10-13,16,47-51}$

Due to the ease of incorporation of functional groups in the organic monolithic matrix, several chromatographic functionalities have been evaluated in applications of CEC and HPLC, such as: hydrophobic interaction in the reversed mode $\left(\mathrm{C}_{4}, \mathrm{C}_{6}, \mathrm{C}_{8}, \mathrm{C}_{18}\right.$, etc. $),{ }^{30-36}$ chiral selectivity, ${ }^{15,34}$ ion exchange ${ }^{14,33,52,53}$ and molecular imprinted selectivity (MIP). ${ }^{15,54}$ However, there are many other characteristics that need to be studied to consolidate these materials as alternatives to particulate stationary phases. These characteristics include fabrication reproducibility, charge capacity, types of functional groups, control of surface chemistry, pore size distribution and the process of molecular diffusion inside the chromatographic bed.

The goal of the present work is the development of monolithic columns from the precursor monomer octadecyl methacrylate to generate a highly hydrophobic organic polymer inside the capillary. There are challenges in preparing high hydrophobicity ODMA (octadecyl methacrylate) monolithic columns since it is necessary to solubilize this monomer together with the porogenic agents and the ionizable monomer, which possess hydrophilic properties. In this work, different solvents were evaluated for preparing polymeric monolithic columns employing the monomers ODMA (octadecyl methacrylate) and EDMA (ethylene dimethacrylate).

\section{Experimental}

\section{Chemicals and materials}

Sodium hydroxide was from Agilent (Waldbronn, Germany); 3-(trimethoxysilyl)propyl methacrylate (TMSPM), N,N-dimethylformamide (DMF), ethylene dimethacrylate (EDMA), octadecyl methacrylate (ODMA), amyl alcohol, isoamyl alcohol, 1,4-butanediol, acenaphthene, acenaphthylene, anthracene, benzo[a] anthracene, benzo[b]fluoranthene, benzo[a]pyrene, chrysene, phenanthrene, fluoranthene, fluorene, naphthalene and pyrene were purchased from Aldrich (Steinheim, Germany); 2,2'-azobisisobutyronitrile (AIBN), 2-acryloylamido-2-methylpropanesulfonic acid (AMPS), ethylbenzene, propylbenzene, butylbenzene and 
pentylbenzene were from Fluka (Steinheim, Germany); cyclohexanol and HPLC grade acetonitrile (ACN) were purchased from J. T. Baker (Phillipsburg, NJ, USA); tris(hydroxymethyl)aminomethane (Tris) was from Fluka (Düsseldorf, Germany).

The standards of methyl paraben, ethyl paraben, propyl paraben and butyl paraben were obtained from Aldrich (Milwaukee, USA). Thiourea was from Riedel-deHaën (Düsseldorf, Germany), and methyl alcohol was from Carlo Erba Reagents (Rodano, Italy). The water used for sample and mobile phase preparation was purified with a Milli-Q deionization system (Millipore SAS., Molsheim, France).

Polyimide coated fused silica capillaries with $75 \mu \mathrm{m}$ inner diameters were from Agilent (Portland, USA).

\section{Instrumentation}

CEC experiments were performed with a CE instrument from Agilent Technologies (Waldbronn, Germany) equipped with a UV-Visible diode-array detector. Data acquisition and processing were performed using HP ChemStation software.

A gas chromatograph oven (Hewlett Packard 5890A) was used for initiating the thermal polymerizations. A LC-10AD HPLC pump from Shimadzu (Kyoto, Japan) and a syringe microchromatography pump (ISCO 260D) were used to condition the columns.

\section{Pretreatment of the capillary}

Using a glass syringe, the capillary was washed and filled with $1 \mathrm{~mol} \mathrm{~L}^{-1}$ sodium hydroxide solution, sealed with glass connectors and kept in an oven at $95^{\circ} \mathrm{C}$ for $2 \mathrm{~h}$. Next, the capillary was flushed with filtered deionized water to neutrality, then with methyl alcohol and dried under purging nitrogen gas for $1 \mathrm{~h}$.

A solution of $50 \%(\mathrm{v} / \mathrm{v})$ of TMSPM in DMF was used to fill the capillary. Both ends were sealed and it was heated in an oven at $100{ }^{\circ} \mathrm{C}$ for $8 \mathrm{~h}$. After, the capillary was washed with DMF and filtered deionized water. Finally, it was again dried with flowing nitrogen.

\section{Preparation of monolithic columns}

Initially, AIBN and AMPS were weighed. For each synthesized phase, about $8.0 \mathrm{mg}$ of initiator agent were added. Next, the solvents were put into a covered glass vial and, in other vials, the monomers (ODMA and EDMA) were placed under a nitrogen stream to avoid contact with air. AMPS and AIBN were added to the vial containing the monomers and, finally, the porogenic solvents were added. Table 1 indicates the capillary columns and the different compositions of the porogenic solvents. The monomer:porogenic solvent ratio was 33:67 (v/v). The proportions of precursor monomer (ODMA), crosslinker (EDMA) and charged monomer (AMPS) were 59.4:40.0:0.6 (w/w/w). The vial was closed and sonicated for $1 \mathrm{~h}$ to homogenize the solution and solubilize the solid reagents.

After solubilization of the monomers with the porogenic solvents, the capillaries were filled with the mixture using a glass syringe. Both ends were sealed with connectors and the remaining solution was left in a closed vial to evaluate the polymerization process outside the capillary. The capillaries and the vial were kept in an oven at $60{ }^{\circ} \mathrm{C}$ for $24 \mathrm{~h}$.

After the polymerization, the capillaries were washed with 70:30 (v/v) acetonitrile:water using the HPLC pump to remove the residual porogenic solvent. The acetonitrile

Table 1. Compositions of the porogenic solvents used in the synthesis of the different columns and their chromatographic and porosimetric parameters

\begin{tabular}{|c|c|c|c|c|c|c|c|c|c|c|c|}
\hline \multirow[t]{2}{*}{ Column } & \multicolumn{5}{|c|}{ Porogenic solvent / \%, v/v } & \multirow[t]{2}{*}{$\begin{array}{c}\mathrm{N}^{\mathrm{a}} / \\
\left(\text { plate } \mathrm{m}^{-1}\right)\end{array}$} & \multirow[t]{2}{*}{$\mathrm{H}^{\mathrm{a}} / \mu \mathrm{m}$} & \multirow[t]{2}{*}{$\mathrm{k}^{\mathrm{a}}$} & \multirow[t]{2}{*}{$\mathrm{L} / \mathrm{cm}$} & \multirow[t]{2}{*}{$\begin{array}{c}\text { Specific surface } \\
\text { area } /\left(\mathrm{m}^{2} \mathrm{~g}^{-1}\right)\end{array}$} & \multirow[t]{2}{*}{$\begin{array}{l}\text { Pore volume / } \\
\left(10^{-3} \mathrm{~cm}^{3} \mathrm{~g}^{-1}\right)\end{array}$} \\
\hline & $\mathrm{A}$ & $\mathrm{B}$ & $\mathrm{C}$ & $\mathrm{D}$ & $\mathrm{E}$ & & & & & & \\
\hline 1 & 75 & 25 & - & - & - & 11600 & 87 & 4.0 & 67.5 & 1.53 & 2.19 \\
\hline 2 & 70 & 30 & - & - & - & 18320 & 55 & 3.6 & 32.2 & 1.86 & 2.62 \\
\hline 3 & 65 & 35 & - & - & - & 25600 & 39 & 3.6 & 70.0 & 2.53 & 3.63 \\
\hline 4 & 75 & 15 & 10 & - & - & 10400 & 96 & 3.1 & 32.0 & 1.90 & 2.45 \\
\hline 5 & 70 & 20 & 10 & - & - & 21800 & 46 & 3.9 & 33.0 & 2.70 & 4.22 \\
\hline 6 & 60 & 30 & 10 & - & - & - & - & - & 35.5 & 5.34 & 10.73 \\
\hline 7 & - & 35 & - & 65 & - & 26000 & 38 & 3.6 & 55.5 & 2.74 & 3.99 \\
\hline 8 & - & 35 & - & - & 65 & 17500 & 57 & 1.9 & 35.5 & 4.31 & 7.99 \\
\hline
\end{tabular}

A: isoamyl alcohol; B: 1,4-butanediol; C: water; D: amyl alcohol; E: cyclohexanol. ${ }^{a}$ Calculated for pentylbenzene. 
and the water were previously passed through a $0.45 \mu \mathrm{m}$ filter and degassed in an ultrasonic bath.

For creating the detection window, aluminum foil was used to delimit a portion of the capillary, about $8 \mathrm{~cm}$ from the extremity of the capillary. The open portion was burned with a lighter to remove the polyimide coating and form the silica window. The burn afforded by lighter removed the polyimide and decomposed the polymeric material present in the region of detection window, which became clear to the UV light of the detector. After preparation of the window, the capillary was washed with a solution of buffer electrolyte (30:70 (v/v) $25 \mathrm{mmol} \mathrm{L}^{-1}$ pH 8.0 Tris:acetonitrile) using the HPLC pump, in order to eliminate fragments produced by the decomposition of the polymer in the detection window zone.

\section{Physical characterization of the monoliths}

\section{Optical microscopy}

Evaluation of column filling was made by optical microscopy with a Motic BA300 microscope (Diadema, Brazil).

\section{Scanning electron microscopy}

Morphological evaluations of the monolithic columns were made by scanning electron microscopy (SEM) using a Jeol GSMT-300 instrument (Tokyo, Japan).

\section{Porosimetry}

The vials containing the polymerized material were submitted to Soxhlet-extraction, having methyl alcohol as solvent, for $24 \mathrm{~h}$ to remove residual porogenic solvents. Next, the materials were dried in an oven at $80^{\circ} \mathrm{C}$ for at least $15 \mathrm{~h}$. The samples were analyzed using an ASAP 2010 porosimetry instrument, based on the method of nitrogen adsorption and desorption. The nitrogen adsorption and desorption isotherms were measured at $77 \mathrm{~K}$. Before proceeding with these measurements, the samples were submitted to degassing for $4 \mathrm{~h}$ at $423 \mathrm{~K}$ under a vacuum of $15 \mathrm{mPa}$. Analysis of the isotherms included the classification of the isotherms obtained, by the BDDT (Brunauer-Demmet-Demmet-Teller) method, and the evaluation of the specific surface area by the BET (Brunauer-Emmet-Teller) method ${ }^{55}$ from the adsorption data in the range of relative pressure $\left(\mathrm{P} / \mathrm{P}_{0}\right)$ of 0.06 to 0.25 , where $\mathrm{P}_{0}$ and $\mathrm{P}$ mean the pressure at saturation and the pressure at each point of nitrogen equilibrium at $77 \mathrm{~K}$, respectively. The total pore volume was evaluated by the single point method ${ }^{55}$ through the conversion of adsorbed nitrogen volume at $\mathrm{P} / \mathrm{P}_{0} 0.995$ to the volume of liquid adsorbate.

\section{Electrochromatographic characterization of the monoliths}

\section{Preparation of electrolyte and samples}

Initially, a stock solution of $100 \mathrm{mmol} \mathrm{L}^{-1}$ Tris buffer was prepared. From this, dilutions were made to $25 \mathrm{mmol} \mathrm{L}^{-1}$ and the $\mathrm{pH}$ value was adjusted to 8.0 through gradual addition of $1 \mathrm{~mol} \mathrm{~L}^{-1} \mathrm{HCl}$.

A $25 \mathrm{mmol} \mathrm{L}^{-1} \mathrm{pH} 8.0$ Tris buffer solution, degassed before use, was added to the sample vial according to the needed proportion for the Tris buffer:acetonitrile electrolyte solution. For example, for a 30:70 (v/v) Tris buffer:acetonitrile mobile phase, $150 \mu \mathrm{L}$ of buffer and $350 \mu \mathrm{L}$ of acetonitrile were mixed.

The test mixture was composed of ethylbenzene, propylbenzene, butylbenzene and pentylbenzene, and a marker compound, thiourea. A stock sample solution of $100 \mathrm{mmol} \mathrm{L}^{-1}$ was prepared in acetonitrile and this was diluted to $5 \mathrm{mmol} \mathrm{L}^{-1}$ in a sample vial for use. The $25 \mathrm{mmol} \mathrm{L}^{-1}$ $\mathrm{pH}$ 8.0 Tris buffer was added in determined proportions (relative to $30 \%$ (v/v)) directly to the sample vial.

A mixture of alkyl parabens (methyl, ethyl, propyl and butyl) was injected at concentrations of $1500 \mu \mathrm{g} \mathrm{mL}$ each. These solutions were prepared in acetonitrile from a stock solution of $1000 \mathrm{mg} \mathrm{mL}^{-1}$ of the parabens dissolved in acetonitrile. Thiourea was added as marker compound, at $500 \mu \mathrm{g} \mathrm{mL} \mathrm{L}^{-1}$.

A test mixture composed of polyaromatic hydrocarbons (PAH) was prepared in acetonitrile and was injected at concentrations of $90 \mu \mathrm{g} \mathrm{mL}^{-1}$ for benzo[a]anthracene,

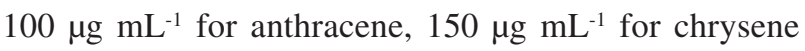
and benzo[a]pyrene, $300 \mu \mathrm{g} \mathrm{mL}^{-1}$ for acenaphtylene, benzo[b]fluoranthene and fluorene and $500 \mu \mathrm{g} \mathrm{mL}^{-1}$ for acenaphthene, phenanthrene, fluoranthene, naphthalene and pyrene. Thiourea was used as marker compound at $500 \mu \mathrm{g} \mathrm{mL}^{-1}$.

\section{Electrochromatographic evaluation}

Before the electrochromatographic evaluation of the synthesized stationary phases, all the solutions utilized during an electrophoretic run (electrolyte and sample solution) were placed in ultrasonic bath for $30 \mathrm{~min}$ for degassing.

The capillary, before testing, was conditioned with a HPLC pump using 30:70 (v/v) $25 \mathrm{mmol} \mathrm{L}^{-1} \mathrm{pH} 8.0$ Tris buffer:acetonitrile.

The capillary was adapted to the electrophoresis cassette and placed in the equipment, being gradually conditioned by increasing the electrical potential by application of 5 , $10,15,20,25$ and $30 \mathrm{kV}$, for $15 \mathrm{~min}$ each, without pressure. Injection was electrokinetic using $10 \mathrm{kV}$ for $5 \mathrm{~s}$. Detection was at $220 \mathrm{~nm}$ for the alkylbenzenes, $254 \mathrm{~nm}$ for the alkyl parabens and $228 \mathrm{~nm}$ for PAH. 


\section{Results and Discussion}

Eight capillaries were synthesized with different compositions of the porogenic solvents, as shown in Table 1 . These solvents were selected according to solubility of monomers in these solvents. Initially, the preparation of the capillaries was based on isoamyl alcohol and 1,4-butanediol, in the presence and absence of water. Using the proportion of porogenic solvents that produced the most efficient column, new columns were prepared substituting isoamyl alcohol with amyl alcohol or cyclohexanol. All the columns were electrochromatographically and physically evaluated, the latter through morphologic analysis of the monolithic material structure by SEM image and by the determination of the specific surface area and pore volume.

\section{Electrochromatographic evaluation}

After synthesis of the monolithic columns, they were conditioned with a HPLC pump to remove any residual material before being placed in the $\mathrm{CE}$ equipment. The electrochromatograms were obtained and the chromatographic parameters of efficiency $(\mathrm{N} / \mathrm{L}$, where $\mathrm{L}$ is the effective length of the column and $\mathrm{N}$ is the plate number), plate height $(\mathrm{H})$ and retention factor $(\mathrm{k})$ were calculated. Table 1 shows the parameters calculated for each column.

As can be seen in Table 1, the capillary column that resulted in the best chromatographic efficiency was number 7 , with a $65: 35(\mathrm{v} / \mathrm{v})$ ratio of the porogenic agents amyl alcohol and 1,4-butanediol. The electrochromatogram obtained with this column is in Figure 1.

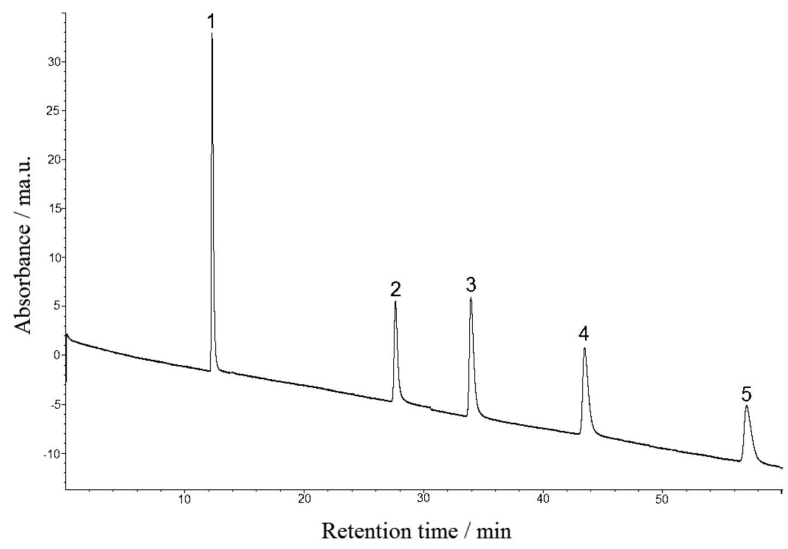

Figure 1. Electrochromatogram of alkylbenzenes and thiourea in capillary 7. Peak identification: 1. thiourea, 2. ethylbenzene, 3. propylbenzene, 4. Butylbenzene and 5. pentylbenzene. Electrophoretic conditions: electrolyte $30: 70(\mathrm{v} / \mathrm{v}) 25 \mathrm{mmol} \mathrm{L}^{-1} \mathrm{pH} 8.0$ Tris buffer:acetonitrile, injection of $10 \mathrm{kV}$ for $5 \mathrm{~s}$, run potential of $30 \mathrm{kV}$, detection at $220 \mathrm{~nm}$ and temperature at $25^{\circ} \mathrm{C}$.
Lower proportions of isoamyl alcohol also were evaluated, but no electrochromatograms could be obtained. When these capillaries were observed by optical microscopy, it was apparent that there was no polymerization of the stationary phase. According to Bernabé-Zafón et al., ${ }^{56}$ larger proportions of 1,4-butanediol can increase the permeability of the monolithic material, caused by earlier phase separation during the polymerization process. This same conclusion is also given by Cantó-Mirapeix..$^{57,58}$

\section{Physical characterization}

For characterizing the morphology of the monolithic structure inside the capillaries, all the synthesized capillaries were examined by scanning electron microscopy. Figure 2 shows photomicrographs of the monolithic stationary phases.

When the photos of the columns containing the monoliths to which water was added to the initial composition are compared with monoliths prepared without water, it can be concluded that the presence of water reduces the domain size of the monoliths. Increasing the content of 1,4-butanediol, the micro- and mesoporogenic agent, narrower macropores were produced, resulting in increased separation efficiency.

For the set of capillary columns prepared in the presence of water, the column made with the largest proportion of 1,4-butanediol (30\%) could not be chromatographically evaluated (column 6). This is consistent with the microscopy obtained for this stationary phase. The high content of 1,4-butanediol caused a decrease in macropores, leading to a significant reduction in the permeability of the column, impeding the chromatographic analysis. The smaller domains and globules observed for column 6 reinforce this explanation.

The porosimetric analysis of the stationary phases was carried out in samples prepared in vials containing the same compositions as the monolithic material prepared in the columns.

Table 1 also reports the values for specific surface area and pore volume for each stationary phase. Initially, it can be noted that the larger the pore volume, the greater is the surface area. Also, the pore size can be controlled by changing the proportions of the porogenic solvents (isoamyl alcohol, amyl alcohol or cyclohexanol, 1,4-butanediol and water).

The capillaries that had the better chromatographic efficiencies possess the largest specific surface areas. According to Peters et al. ${ }^{59}$ higher surface areas and pore volumes usually mean higher chromatographic efficiencies because more area of the stationary phase is 

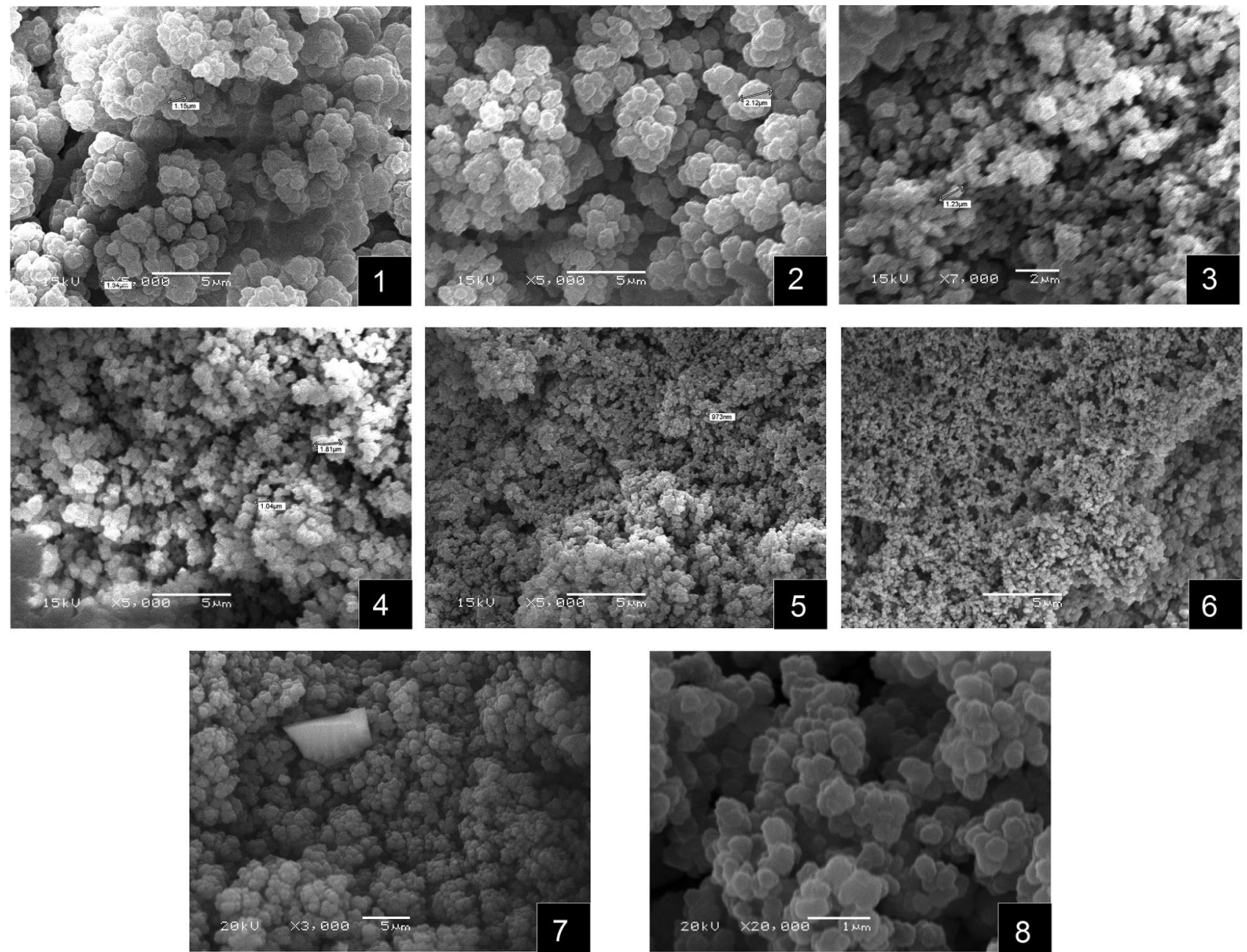

Figure 2. SEM images of the organic monolithic stationary phases. Magnification 5000 for columns 1, 2, 4, 5 and 6,7000 for column 3, 3000 for column 7 and of 20000 for column 8.

available to interact with the analytes as they pass through the column.

In relation to the porogenic solvents used in the synthesis of the stationary phases, it can be observed that the specific surface areas are greater with larger contents of 1,4-butanediol in the composition of the porogenic agents because this solvent is both a micro- and a mesoporogenic agent. The chain size of this solvent is smaller than the other alcohols used as porogenic solvents. With increasing content of 1,4-butanediol, for columns prepared in the presence and the absence of water, the globules become smaller, leading to increased surface area.

The values relative to specific surface area, all smaller than $6 \mathrm{~m}^{2} \mathrm{~g}^{-1}$, are similar to values cited in the literature ${ }^{59}$ for organic monolithic columns.

For all the stationary phases, the nitrogen adsorption and desorption isotherms were very similar and, according to the BDDT (Brunauer-Deming-Deming-Teller) classification, they can be considered isotherms type IV due to the short loop of hysteresis in the desorption branch. ${ }^{60}$ According to Vansant et al., ${ }^{61}$ these types of isotherms are characteristic of mesoporous materials, which show a distinct hysteresis loop under high pressures, because the desorption branch does not follow the adsorption branch, indicating that the evaporation of gas is different from the condensation step. ${ }^{62}$ In the isotherms of these phases, the hysteresis is closed in the region close to saturation, ${ }^{60}$ as confirmed by the pore size distribution curves. Furthermore, the hysteresis visualized at the relatively low pressure region indicates that the system has micropores, as defined by Sing et al. ${ }^{63}$ At lower relative pressures, a sharp kink was observed due to the higher adsorption potential of the micropores, also explained by Bereznitski et al. ${ }^{64}$ Figure 3 presents the isotherm for material 7, which each branch indicates a phenomena: the nitrogen absorption (ascendant arrow) and the nitrogen desorption (descendent arrow).

It is then concluded that the monolithic stationary phases developed in this work have three types of possible pores: micro-, meso- and macropores. This result is 


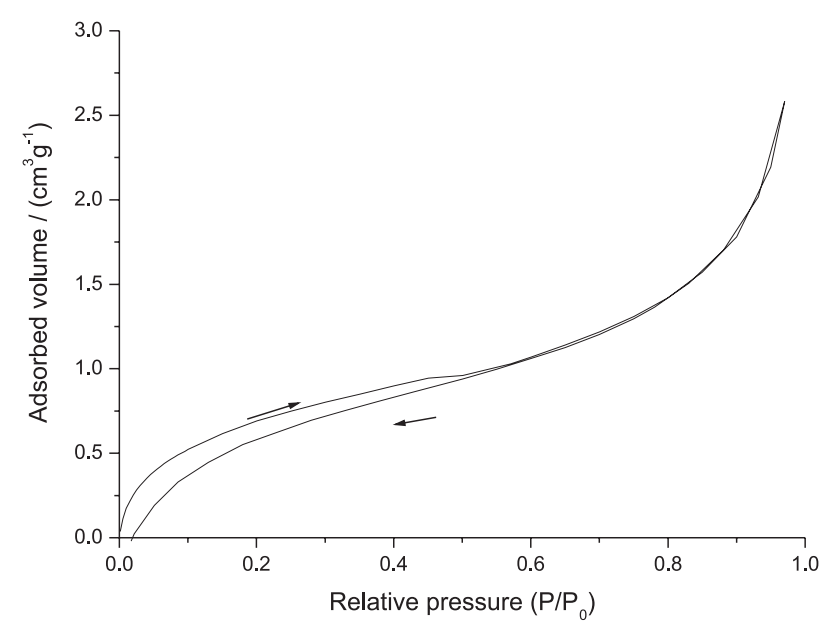

Figure 3. Adsorption and desorption isotherms for stationary phase 7.

consistent with the ease of flow of mobile phase through the capillaries, supported by SEM microscopy and porosimetry.

\section{Alkyl paraben separation}

Alkyl parabens are compounds with apolar characteristics that permit hydrophobic interactions with the apolar monolithic stationary phase. Alkyl parabens were separated with column 7 , varying the compositions of mobile phase to obtain the best chromatographic separation of the analytes with baseline resolution, as shown in Figure 4.

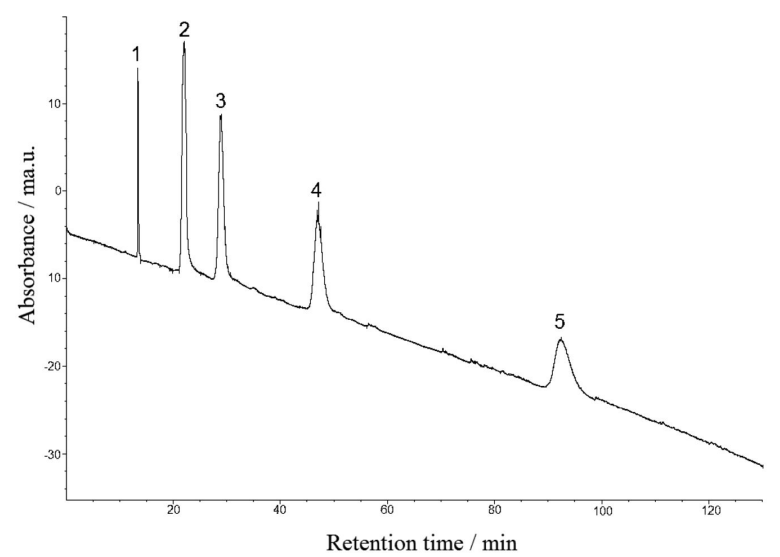

Figure 4. Electrochromatogram of an alkyl parabens mixture in capillary 7. Peak identification: 1. thiourea, 2. methyl paraben, 3. ethyl paraben, 4. propyl paraben, 5. butyl paraben. Electrophoretic conditions: electrolyte $70: 30(\mathrm{v} / \mathrm{v}) 25 \mathrm{mmol} \mathrm{L}^{-1} \mathrm{pH} 8.0$ Tris buffer:acetonitrile, injection of $10 \mathrm{kV}$ for $5 \mathrm{~s}$, run potential of $30 \mathrm{kV}$, detection at $254 \mathrm{~nm}$ and temperature at $25^{\circ} \mathrm{C}$.

\section{PAH separation}

Polycyclic aromatic hydrocarbons (PAH) are very apolar neutral compounds and should have effective interactions with the stationary phase synthesized in this work.
Twelve PAH also were separated on column 7 using an optimized separation. Figure 5 shows the electrochromatogram. The best condition was buffer solution 50:50 (v/v) $25 \mathrm{mmol} \mathrm{L}^{-1} \mathrm{pH} 8.0$ Tris:acetonitrile as mobile phase.

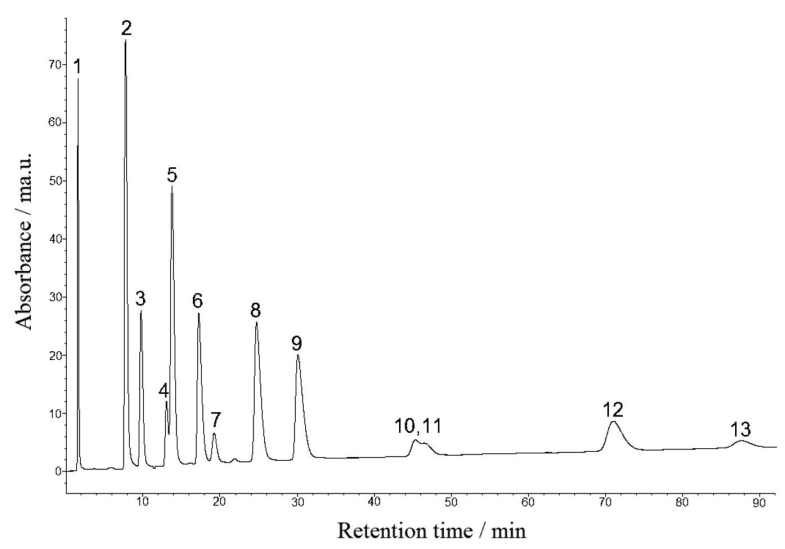

Figure 5. Electrochromatogram of $12 \mathrm{PAH}$ in capillary 7. Peak identification: 1. thiourea, 2. naphthalene, 3. acenaphtylene, 4. fluorene, 5. acenaphtene, 6. phenanthrene, 7. anthracene, 8. fluoranthene, 9. pyrene, 10. chrysene, 11 . benzo[a]anthracene, 12 . benzo[b]fluoranthene, 13. benzo[a]pyrene. Electrophoretic conditions: electrolyte 50:50 (v/v) $25 \mathrm{mmol} \mathrm{L}^{-1} \mathrm{pH} 8.0$ Tris buffer:acetonitrile, injection of $10 \mathrm{kV}$ for $5 \mathrm{~s}$, run potential of $30 \mathrm{kV}$, detection at $228 \mathrm{~nm}$, temperature at $25^{\circ} \mathrm{C}$.

\section{Conclusions}

Monolithic columns for electrochromatography were developed and separated alkyl parabens and polycyclic aromatic hydrocarbons (PAH). Since one of the precursor monomers for the preparation of the stationary phase was octadecyl methacrylate $\left(\mathrm{C}_{18}\right)$, this highly apolar group aids in the separation of these hydrophobic compounds.

The columns prepared with either amyl alcohol or isoamyl alcohol as porogenic agents in the proportion 65:35 (v/v) with 1,4-butanediol had the best chromatographic efficiencies, resulting in plate heights of about $39 \mu \mathrm{m}$.

The microscopies of the synthesized capillaries allowed observing that the columns with greater efficiency had smaller globules and higher amounts of micro- and mesopores, responsible for an increased specific surface area for these stationary phases.

\section{Acknowledgments}

The authors ackonowledge the financial support of the Fundação de Amparo à Pesquisa do Estado de São Paulo (FAPESP) and of the Conselho Nacional de Desenvolvimento Científico e Tecnológico (CNPq). The authors also thank Professor Carol H. Collins for language assistance. 


\section{References}

1. Krull, I. S.; Stevenson, R. L.; Mistry, K.; Swartz, M. E.; Capillary Electrochromatography and Pressurized Flow Capillary Electrochromatography. An Introduction; HNB Publishing: New York, USA, 2000.

2. Weinberger, R.; Practical Capillary Electrophoresis; CE Technologies, Inc.; Chappaqua: New York, USA, 2000.

3. Hilder, E. F.; Svec, F.; Fréchet, J. M. J.; J. Chromatogr., A 2004, 1044, 3.

4. Buszewski, B.; Szumski, M.; Chromatographia 2004, 60, s261.

5. Bartle, K. D.; Myers, P.; J. Chromatogr., A 2001, 916, 3.

6. Danquah, M. K.; Forde, G. M.; Chem. Eng. J. 2008, 140, 593.

7. Pursch, M.; Sander, L. C.; J. Chromatogr., A 2000, 887, 313.

8. Bartle, K. D.; Carney, R. A.; Cavazza, A.; Cikalo, M. G.; Myers, P.; Robson, M. M.; Roulin, S. C. P.; Sealey, K.; J. Chromatogr., A 2000, 892, 279.

9. Jiskra, J.; Claessens, H.; Cramers, C. A.; J. Sep. Sci. 2003, 26, 1305.

10. Legido-Quigley, C.; Marlin, N. D.; Melin, V.; Manz, A.; Smith, N. W.; Electrophoresis 2003, 24, 917.

11. Allen, D.; El Rassi, Z.; Electrophoresis 2003, 24, 3962.

12. Li, W.; Fries, D. P.; Malik, A.; J. Chromatogr., A 2004, 1044 , 23.

13. Lin, J.; Wu, X.; Lin, X.; Xie, Z.; J. Chromatogr., A. 2007, 1169, 220.

14. Lin, J.; Huang, G.; Lin, X.; Xie, Z.; Electrophoresis 2008, 29 , 4055.

15. Eeltink, S.; Svec, F.; Electrophoresis 2007, 28, 137.

16. Courtois, J.; Szumski, M.; Georgsson, F.; Irgum, K.; Anal. Chem. 2007, 79, 335 .

17. Segato, M. P.; Silva, C. R.; Jardim, I. C. S. F.; Quím. Nova 2009, 32,431

18. Hoegger, D.; Freitag, R.; J. Chromatogr., A 2003, 1004, 195.

19. Ishizuka, N.; Minakuchi, H.; Nakanishi, K.; Hirao, K.; Tanaka, N.; Colloids Surf., A 2001, 187-188, 273.

20. Miyabe, K.; Cavazzini, A.; Gritti, F.; Kele, M.; Guiochon, G.; Anal. Chem. 2003, 75, 6975.

21. Huclová, J.; Satínský, D.; Karlícek, R.; Anal. Chem. Acta 2003, 494, 133.

22. Li, Y.; Tolley, H. D.; Lee, M. L.; Anal. Chem. 2009, 81, 9416.

23. Okanda, F. M.; El Rassi, Z.; Electrophoresis 2005, 26, 1988.

24. Karenga, S.; El Rassi, Z.; J. Sep. Sci. 2008, 31, 2677.

25. Xu, Z.; Yang, L.; Wang, Q.; J. Chromatogr., A 2009, 1216, 3098.

26. Lerma-García, M. J.; Simó-Alfonso, E. F.; Ramis-Ramos, G.; Herrero-Matínez, J. M.; Electrophoresis 2008, 29, 4603.

27. Núñez, O.; Ikegami, T.; Miyamoto, K.; Tanaka, N.; J. Chromatogr., A 2007, 1175, 7.

28. Tanret, I.; Mangelings, D.; Heyden, Y. V.; Electrophoresis 2008 , $29,4463$.
29. Ueki, Y.; Umemura, T.; Iwashita, Y.; Odake, T.; Haraguchi, H.; Tsunoda, K.; J. Chromatogr., A 2006, 1106, 106.

30. Ueki, Y.; Umemura, T.; Iwashita, Y.; Tsunoda, K.; Haraguchi, H.; Chem. Lett. 2005, 34, 1198.

31. Tanret, I.; Mangelings, D.; Heyden, Y. V.; J. Pharm. Biomed. Anal. 2008, 48, 264.

32. Mangelings, D.; Tanret, I.; Meert, V.; Eeltink, S.; Schoenmakers, P. J.; Kok, W. Th.; Heyden, Y. V.; J. Chromatogr. Sci. 2007, 45, 578.

33. Quigley, C. L.; Marlin, N.; Smith, N. W.; J. Chromatogr., A 2004, 1030, 195.

34. Preinerstorfer, B.; Bicker, W.; Lindner W.; Iämmerhofer, M.; J. Chromatogr., A 2004, 1044, 187.

35. Buszewski, B.; Szumski, M.; Sus, S.; LC-GC Europe 2002, 15, 792.

36. Jiang, Z.; Smith, N. W.; Ferguson, P. D.; Taylor, M. R.; J. Biochem. Biophys. Methods 2007, 70, 39.

37. Ou, J.; Gilson, G. T. T.; Oleschik, R. D.; J. Chromatogr., A 2010, $1217,3628$.

38. Karenga, S.; El Rassi, Z.; Electrophoresis 2010, 31, 991.

39. Tunç, Y.; Gölgelioglu, Ç.; Hasirci, N.; Ulubayram, K.; Tuncel, A.; J. Chromatogr., A 2010, 1217, 1654.

40. Anderson, G. J.; LaPier, Z.; Cammarata, M. B.; Cullum, T. S.; Bushey, M. M.; Electrophoresis 2010, 31, 1583.

41. Bernabé-Zafón, V.; Beneito-Cambra, M.; Simó-Alfonso, E. F.; Herrero-Martínez, J. M.; J. Chromatogr., A 2010, 1217, 3231.

42. Abbood, A.; Herrenknecht, C.; Proczek, G.; Descroix, S.; Rodrigo, J.; Taverna, M.; Smadja, C.; Anal. Bioanal. Chem. 2011, 400, 459.

43. Karenga, S.; El Rassi, Z.; Electrophoresis 2011, 32, 1033.

44. Karenga, S.; El Rassi, Z.; Electrophoresis 2011, 32, 1044.

45. Merhar, M.; Podgornik, A.; Barut, M.; Zigon, M.; Strancar, A.; J. Sep. Sci. 2003, 26, 322.

46. Greiderer, A.; Trojer, L.; Huck, C. W.; Bonn, G. K.; J. Chromatogr., A 2009, 1216, 7747.

47. Svec, F.; J. Sep. Sci. 2005, $28,729$.

48. Eeltink, S.; Rozing, G. P.; Kok, W. Th.; Electrophoresis 2003 , 24,3935

49. Eeltink, S.; Rozing, G. P.; Schoenmakers, P. J.; Kok, W. T.; J. Chromatogr., A 2006, 1109, 74.

50. Puy, G.; Demesmay, C.; Rocca, J. L.; Iapichella, J.; Galarneau, A.; Brunel, D.; Electrophoresis 2006, 27, 3971.

51. Augustin, V.; Jardy, A.; Gareil, P.; Hennion, M. C.; J. Chromatogr., A 2006, 1119, 80.

52. Thabano, J. R. E.; Breadmore, M. C.; Hutchinson, J. P.; Johns, C.; Haddad, P. R.; J. Chromatogr., A 2007, 1175, 117.

53. Wang, X.; Lin, X.; Xie, Z.; Giesy, J. P.; J. Chromatogr., A 2009, $1216,4611$.

54. Haginaka, J.; Futagami, A.; J. Chromatogr., A 2008, 1185, 258.

55. Gregg, S. J.; Sing, K. S. W.; Adsorption, Surface Area and Porosity; Academic Press: London, UK, 1982. 
56. Bernabé-Zafón, V.; Cantó-Mirapeix, A.; Simó-Alfonso, E. F.; Ramis-Ramos, G.; Herrero-Martínez, J. M.; Electrophoresis 2009, 30, 1929.

57. Cantó-Mirapeix,A.; Herrero-Martínez, J. M.; Mongay-Fernández, C.; Simó-Alfonso, E. F.; Electrophoresis 2009, 30, 599.

58. Cantó-Mirapeix,A.; Herrero-Martínez, J. M.; Mongay-Fernández, C.; Simó-Alfonso, E. F.; Electrophoresis 2008, 29, 4399.

59. Peters, E. C.; Petro, M.; Svec, F.; Fréchet, J. M. J.; Anal. Chem. 1997, 69, 3646.

60. Webb, P. A.; Orr, C.; Analytical Methods in Fine Particle Technology; Micromeritics Instrument Corporation: Norcross, USA, 1997.

61. Vansant, E. F.; van der Voort, P.; Vrancken, K. C.; Characterization and Chemical Modification of the Silica Surface; Elsevier: Amsterdam, Holland, 1995.
62. Teixeira, V. G.; Coutinho, F. M. B.; Gomes, A. S.; Quím. Nova 2001, 24, 808.

63. Sing, K. S. W.; Everett, D. H.; Haul, R. A. W.; Moscou, L.; Pierotti, R. A.; Rouquérol, J.; Siemieniewska, I.; Pure Appl. Chem. 1985, 57, 603.

64. Bereznitski, Y.; Jaroniec, M.; Gangoda, M. E.; J. Chromatogr., A 1998, 828, 59.

Submitted: October 17, 2012

Published online: March 12, 2013

FAPESP has sponsored the publication of this article. 